\title{
Chapter 9 \\ Diaspora Policies, Consular Services and Social Protection for Estonian Citizens Abroad
}

\author{
Maarja Saar
}

\subsection{Diaspora Policy Infrastructure and Key Policies}

This chapter focuses on Estonian policies oriented towards nationals abroad. The main premise is that the Estonian diaspora policy has largely been culture and language focused and paid little attention to social protection. The chapter also suggests that the focus is shifting away from language and culture and becoming more business oriented, with initiatives such as the e-residency and the Global Estonian Network. The diaspora in this context is seen as useful for reviving the country's economy and providing access to foreign markets.

Furthermore, one can speculate that an important shift in respect to return migration is taking place. For several years, Estonian policies have been geared towards supporting outmigration and treating return migration as a natural part of the process. This is evident, for instance, from the Social Minister Hanno Pevkur who claimed in 2010 the outmigration of Estonians was not a problem and was mostly related to economic issues. However, he continued, these Estonians would surely return one day due to their loyalty for the country (see Raus 2010). Even though the state has in a small measure supported return migration through fiscal means, few returnees have used the scheme. This chapter also points out that policy-makers' attitude towards migration is now slowly changing, as the country is facing both the inflow of foreign migrants and the return of Estonian migrants with family members who do not speak the language and face integration difficulties. Therefore, the state has introduced several language and culture programmes as well as courses introducing the Estonian labour market to foreigners.

M. Saar $(\bowtie)$

Södertörn University, Huddinge, Sweden

e-mail: Maarja.saar@sh.se 


\subsubsection{The Estonian Diaspora and Its Relations with the Homeland}

Tammaru et al. (2010) note that the Estonian diaspora has been formed by three major waves of outmigration, two in the past and one ongoing since 1991. The first and largest wave started in mid-nineteenth century, lasted until the outbreak of World War I in 1914, and was predominantly eastwards. Tammaru et al. (2010) explain that this flow resulted from the limited options for urban migration for Estonia's rural communities that pushed many people to seek opportunities in Russia. By the start of World War I, out-migrants to Russia amounted to about $20 \%$ of Estonia's population. They established many Estonian settlements across Russia. However, many of these people decided later to return to Estonia. The second historical wave comprised refugees from the emergent Soviet regime in the country during World War II and was mostly oriented towards the West, with Sweden and Germany as the main host countries, but also the United States of America (USA) and Canada. Tammaru et al. (2010) estimate that the number of World War II refugees from Estonia to around 70,000-80,000. Unlike the eastwards diaspora that steadily decreased over a period of six decades, the diaspora towards the West remained relatively constant over time. For instance, the fact that Estonia regained independence in 1991 had a significant effect on the number of Estonians living in Russia, with half of them returning back to Estonia. By contrast, the events of 1991 had little effect on the diaspora residing in the USA or Canada.

The third and most recent wave of migration from Estonia is a westwards movement ongoing since the regaining of independence. This new wave has been characterised by heavy circular migration, as well as return migration (Saar 2016). The main destination country for these more recent migrants has been Finland. ${ }^{1}$ Due to the geographical proximity of Finland, a new type of migrant has emerged - the cross-border commuter (Fröhlig et al. 2017). They are mostly male migrants who maintain their families in Estonia while working in nearby countries such as Finland, Sweden and Norway. An interesting aspect about the third wave of migration is that the general educational level of these migrants is lower than that of the Estonian population in general (Anniste et al. 2012). Furthermore, Anniste et al. (2012) have found highly skilled migrants are more likely to return to Estonia than low skilled. This, as this chapter will later suggest, can be related to Estonia's neoliberal political direction. Even though a great number of third wave migrants from Estonia can be considered economically motivated, new and important motivations related to personal and career development as well as the availability of higher studies abroad, have emerged. For the latter purposes, the United Kingdom (UK) seems to be the preferred destination (Saar 2018).

\footnotetext{
${ }^{1}$ Statistika Amet 2017. Eesti Statistkaamet. Väljaränne soo, vanuse ja sihtriigi järgi. http://pub.stat. ee/px-web.2001/Dialog/varval.asp?ma=RVR04\&ti=V\%C4LISR\%C4NNE+SOO\%2C+VANUSE R\%DCHMA+JA+L\%C4HTE\%2FSIHTRIIGI+J\%C4RGI\&path=../Database/Rahvastik/03Rahva stikusundmused/08Ranne/\&lang=2. Accessed 16 April 2019.
} 
There was another migration flow, chronologically the third, between 1940 and $1989 / 1990$, which has had a major impact on Estonian migration policies. This was the flow of immigrants from the Soviet Union, most of which Russians and Russianlanguage speakers. Currently, about $30 \%$ of the Estonian population is Russianspeaking, this including people from other Slavic countries such as Belorussia and Ukraine. ${ }^{2}$ The presence of a large Russian minority in Estonia has resulted in the state viewing dual citizenship as illegal. The policy is primarily aimed at motivating the Russian-speaking population to apply for Estonian citizenship because there is a strong negative stance towards people having dual citizenship of both Russia and Estonia. Nevertheless, the presence of the sizeable Russian-speaking population in Estonia has resulted in pension agreements with Russia. Still, the tensions concerning dual citizenship have led to the major focus on migration and integration related issues being on the Russian-speakers and less on Estonians abroad.

Overall, Estonian migration flows could be characterized as being four major waves: the outflow of Estonians towards Russia from the 1850s up until the beginning of World War I; the outflow of Estonian refugees to the West during World War II; the inflow of Russian-speakers during the Soviet period 1940-1941 and 1945-1990; and finally, the outflow of (economic) migrants to the West after Estonia regained independence in 1991.

\subsubsection{Diaspora Infrastructure}

Estonia does not have a special ministry or a subsection of the ministry that specifically deals with co-nationals abroad. Therefore, the responsibilities concerning this segment of the population are divided between different ministries, such as the ones responsible for Foreign Affairs, Culture, Education and Social Affairs. In addition, some foundations engage with issues related to all nationals abroad, such as the Foundation of Integration and agencies such as the Estonian Agency for Research. Both foundations are administered by the state. The Ministry of Culture is responsible for the Foundation of Integration, while the Ministry of Education is responsible for the Estonian Agency for Research.

Estonia has consulates in 34 countries, ${ }^{3}$ as well as a number of honorary consulates, ${ }^{4}$ but does not have any mobile consular services. There is a higher

\footnotetext{
${ }_{2}^{2}$ Statistika Amet 2017. Statistikaamer. Rahvastik soo, vanuse, rahvuse ja maakonna järgi. http:// pub.stat.ee/px-web.2001/Dialog/varval.asp?ma=RV0222U\&ti=RAHVASTIK+SOO\%2C+RAHV USE+JA+MAAKONNA+J\%C4RGI\%2C+1\%2E+JAANUAR $\% 2 \mathrm{E}+\mathrm{HALDUSJAOTUS+SEISUG}$ $\mathrm{A}+01 \% 2 \mathrm{E} 01 \% 2 \mathrm{E} 2018 \& \mathrm{path}=. . / \mathrm{Datab} a \mathrm{se} / \mathrm{Rahvastik} / 01 \mathrm{Rahvastikunaitajad}$ ja koosseis/04Rahvaarv_ja_rahvastiku_koosseis/\&lang=2. Accessed 16 April 2019.

${ }^{3}$ Ministry of Foreign Affairs, Estonian Embassies. https://vm.ee/et/riigid/eesti-saatkonnad. Accessed 16 April 2019.

${ }^{4}$ Ministry of Foreign Affairs, Estonian Honorary Consuls. https://vm.ee/et/riigid/eesti-aukonsulid. Accessed 16 April 2019.
} 
number of consulates in the countries to which Estonia's World War II refugees fled, such as the previously mentioned World War II refugee host countries. A recent development, due to the high inflow of Estonians to Finland, is that Estonia now has in addition to the consulate in Helsinki, eight honorary consuls spread throughout Finland. In addition to consulates, there are Estonian community organizations that operate in many countries such as Finland, Sweden, Germany, the USA, etc., which the Estonian Government has financially supported in the past. However, since the support is mostly project-based, it is more difficult to map the exact extent of this state support for those organizations. The activities of these organizations vary, ranging from offering Estonian language courses to providing legal help, which depends on the availability of pertinent expertise.

In respect of whom the state regards as a national abroad, the consulates usually refer to people holding Estonian citizenship. The Estonian state does not allow dual citizenship for adults (over 18 years of age), although this is practiced in reality by Estonian citizens that apply for citizenship in countries which do allow dual citizenship. In the context of culture and education, state programs use the word väliseestlased (compatriots). ${ }^{5}$ Interestingly, in the Program for Compatriots 2014-2020 (Rahvuskaaslaste Programm 2014-2020), ${ }^{6}$ väliseestlased is not a clearly defined group. Furthermore, the report does not clarify whether the word refers only to nationals holding an Estonian passport or to nationals claiming an Estonian ethnic origin as well. This report is not an exception, as programs and institutions in Estonia rarely define who they include as Estonians, although they do refer most frequently to the population abroad as Estonians abroad. Furthermore, the Ministry of Education and Research does not clearly define who the institution includes as Estonians. ${ }^{7}$ Therefore, it could be concluded that the term is rather loose and usually includes people having ethnic roots tying them to Estonia.

However, in the context of political participation, the term is slightly clearer. All Estonian citizens, irrespective of their residence in Estonia or abroad can vote in national parliamentary elections. ${ }^{8}$ The location of primary place of residence in a particular municipality within the borders of Estonia enables all Estonians to vote. Estonian parties' activism abroad is limited and the issues around citizens abroad receive very little attention from them. Still, the Estonian Conservative People's Party has established a subsection in Finland to attract the diaspora's vote and a few other parties advertised on billboards in Helsinki during the last parliamentary elections.

\footnotetext{
${ }^{5}$ Education Agency. Compatriots Scholarship. http://haridus.archimedes.ee/en/compatriots-scholarships. Accessed 16 April 2019.

${ }^{6}$ Ministry of Education and Research. Program for Compatriots 2014-2020. https://www.hm.ee/ sites/default/files/rahvuskaaslaste_programm_2014_2020.pdf. Accessed 16 April 2019.

${ }^{7}$ Ministry of Education and Research. Estonians abroad. https://www.hm.ee/et/tegevused/eestikeel-ja-voorkeeled/eestlased-valismaal. Accessed 16 April 2019.

${ }^{8}$ Riigi Teataja. Riigikogu valimise seadus. https://www.riigiteataja.ee/akt/28675. Accessed 16 April 2019.
} 


\subsubsection{Key Engagement Policies}

In the context of policies of engagement with nationals abroad who account for just over $15 \%$ of the total population, the main focus is on language and culture (see Jakobson 2017).

Estonia has been financing the Program for Compatriots (Rahvuskaaslaste Programm) since 2004. The program is primarily funded by the Ministry of Education and Research and that of Culture, with support from the Ministries of Foreign Affairs, Internal Affairs and the National Archive. So far, the program has completed two rounds in 2004-2008 and 2009-2013 and is in the midst of a third round 2014-2020. The latest round is tightly connected to the 'Estonian Language Development Plan 2011-2017' and the 'Foundations of Cultural Policy until 2020'. The program has four objectives: teaching Estonian abroad, and supporting the study in Estonia of nationals abroad; the preservation of Estonian culture abroad and support for the formation of Estonian feelings of cohesion; supporting the collection, preservation and availability of an exile cultural heritage (an archival action) and encouraging the return of foreign Estonians to Estonia. Regarding the support for Estonian language teaching abroad, it is worth mentioning that there were approximately 3500 children of expatriates who were studying Estonian in September 2017 (Reimaa 2017). The program has changed its focus in recent years however. Earlier measures were mostly directed towards Estonian communities in the 'East' defined as former communist areas and the former Soviet Union which, as Adamson (2009) explained, includes communities in Ukraine, Siberia and Petseri. The latest reforms, however, have also included new migrants in the West (mainly Western European countries such as Germany, Belgium or the UK, according to the Program for Compatriots). Currently, 63 Estonian-language teaching establishments are supported, as well as 80 general education and Sunday schools, societies, kindergartens, playgroups and Estonian language courses (Madison 2018). The original motivating factors for focusing on Estonians in the eastern territories in the 1990s was their poor economic position, and their higher profile activities (Jakobson 2017). The first round of the Rahvuskaaslaste Programm supported cultural associations in the East, research dedicated to the Eastern diaspora and cultural heritage. An analysis of the influence of the Rahvuskaaslaste Programm indicates the most impacted area has been language teaching. ${ }^{9}$ The latest round (2014-2020) has dedicated special attention to supporting secondary education in Estonian initially in countries such as Finland and Sweden, but later also in Belgium, Spain, Luxembourg and Germany (Jakobson 2017). In addition to the onsite language training, an online environment for language studies has been created. ${ }^{10}$

In addition to the Rahvuskaaslaste Programm, the Integration Foundation (Intergratsiooni Sihtasutus) has been organizing summer camps intended for young people with Estonian roots aged 13 to 18 years. In the scope of Rahvuskaaslaste

\footnotetext{
${ }^{9} \mathrm{https}: / /$ www.hm.ee/sites/default/files/ty_rahvuskaaslaste_uuring.pdf. Accessed 16 April 2019.

${ }^{10}$ www.keeleklikk.ee. Accessed 16 April 2019.
} 
Programm, scholarships for youths with Estonian roots are provided in case they are interested in studying in Estonian higher education or vocational schools. The aim is to support the studies of young expatriate Estonians in Estonian public universities, national institutions of applied higher education and vocational education centres. Applications for scholarships are invited from young expatriate Estonians who have not resided in Estonia on a permanent basis for at least the last 10 years and who possess a secondary or higher education. ${ }^{11}$

According to the final evaluation of the impact, Rahvuskaaslaste Programm was least successful in the four key areas supporting return migration (Aksen et al. 2015). As the evaluation report refers, many expatriates feel the Estonian state is not ready to look after their welfare. This is usually illustrated by referring to the problems with finding school and kindergarten places, the lack of information and the difficulties of integrating into the labour market. Another key issue expatriates referred to is accessibility to the state's repatriation support. This is a one-time support payment with a maximum value of 2000 euro to facilitate the return of those Estonian citizens who are struggling financially. However, the support is only available for those Estonians who have been away for 10 years or more, and thus so far people who migrated after the economic crisis in 2009 have not been able to claim.

Under the scope of Rahvuskaaslaste Programm, many Estonian organizations abroad have received some support. For instance, the Association of Estonians in Sweden announces on its webpage that it has received help through the Programme.

In the context of other more general developments in diaspora policy, Enterprise Estonia (a non-profit foundation) has created a website 'Global Estonian Network' 12 that is designed to function as a contact network for Estonians abroad. Despite not being funded by the Estonian Government, the project was included in the action plan for the Government which took office in 2015. The objective is to connect Estonians abroad who have experience with conducting business with Estonian companies to help them access foreign markets. This is an example of how the Estonian diaspora is 'used' for the benefit of Estonia.

Another initiation that only has an indirect connection with diaspora politics has been the e-residency. The program allows non-Estonians to access to Estonian services such as company formation, banking, payment processing, and taxation. The program gives the e-resident a smart card that they can use to sign documents. The program is aimed towards entrepreneurs for whom physical location is least important (e.g. software developers, writers, etc.). By September 2018, there had been 46,919 applications for e-residency, of which 44,783 were accepted. About $40 \%$ of the applicants list their main motivation for e-residency as having an international business not dependent on the location (hence finding it convenient to register their company in Estonia). 26\% expressed a wish to bring their companies to Estonia. Relatively few actually want to live or visit Estonia (6\%). Most of the successful

\footnotetext{
${ }^{11}$ Education Agency. Compatriots Scholarship. http://haridus.archimedes.ee/en/compatriots-scholarships. Accessed 16 April 2019.

${ }^{12}$ https://globalestonian.com/en/about. Accessed 16 April 2019.
} 
e-residency applicants live in Finland, followed by Russia, Ukraine, Germany and the USA (i.e. states, with the exception of the CIS, that are major host countries for the Estonian diaspora). ${ }^{13}$ However, it is relatively unclear what connection e-residents had with Estonia before applying. Thus, there could be some members of the diaspora among e-residents, especially considering that Estonia does not allow dual citizenship. E-residency could ease developing business relations with Estonia for the diaspora.

As previously mentioned, when it comes to voting, Estonian citizens residing abroad are allowed to participate in general parliamentary elections. ${ }^{14}$ Nationals abroad can participate in pre-voting where they do not have to be members in particular municipality in order to vote from there. Additionally, there is an option to vote electronically. Estonian citizens residing abroad cannot vote in municipal elections however. They have the right to be a candidate in parliamentary elections, however cannot run in local elections.

As observed, Estonia prioritizes teaching Estonian language in foreign countries above other policy fields. A viable hypothesis for this choice is that Estonian politics views outmigration as inevitable and 'natural'. Indeed, Sippola (2013) suggests the Estonian state treats its citizens as profit maximisers, which does not encourage their loyalty. However, an alternative hypothesis would be as the state views individuals as economic entities; outmigration occurs for an individual's economic benefit and is, therefore, not a social problem. Hence, loyalty for Estonia is not necessarily maintained by presence in the country, but through investing into learning Estonian language and culture. Furthermore, it could be proposed that there is a growing interest in capitalizing on the loyalty of expatriates for business purposes, through initiatives such as the Global Estonian Network.

\subsection{Diaspora Policies and Social Protection in Estonia}

Estonia overall does not have well-established means for helping Estonians abroad in matters of social protection. In general, only basic consular services (such as ordering passports, legalization of documents, issuing marriage certificates, issuing Estonian driving licences, etc.) are available through the consulates. ${ }^{15}$ Information for Estonian citizens abroad is mainly provided through consulates' homepages, ${ }^{16}$ which also include very basic information on social protection. The Ministry of Foreign Affairs also provides some general and basic information for travellers for

\footnotetext{
${ }^{13}$ Republic of Estonia E-residency. E-Residency Data dashboard. https://app.cyfe.com/dashboard s/195223/5587fe4e52036102283711615553. Accessed 16 April 2019.

${ }^{14}$ Riigi Teataja. Riigikogu valmise seadus. https://www.riigiteataja.ee/akt/1045561. Accessed 16 April 2019.

${ }^{15}$ Riigi Teataja. Konsulaarseadus. https://www.riigiteataja.ee/akt/KonS. Accessed 16 April 2019.

${ }^{16}$ See e.g. Eesti suursaatkond Helsingi. Konsulaarinfo. http://www.estemb.fi/eng. Accessed 16 April 2019.
} 
each of the world's countries ${ }^{17}$ in addition to the information available through the EU-funded EURES website. ${ }^{18}$ Additionally, the main providers of social insurance, which in Estonia are mostly public institutions, usually have subsections on their websites for citizens abroad. This is the case, for example, for the national Health Insurance Fund (Haigekassa). ${ }^{19}$ In terms of general information strategy, it seems that Estonians abroad are largely expected to be self-sufficient and capable of finding their way through social insurance matters on their own (see Fröhlig, Saar and Runfors 2017). In addition to state supported sources of information, some local communities have organized alternative means for gaining knowledge about destination countries' social insurance systems. For instance, Estonians in Sweden can receive important legal information from a specific webpage. ${ }^{20}$ This type of resources is also available to diaspora communities, but frequently the platforms are not state supported.

Regarding the need to register residence abroad, Estonia has the peculiarity of not requiring citizens who leave to deregister from its national population register. Therefore, official statistics on how many Estonians are living abroad can sometimes be untrustworthy, as many migrants might still be registered in Estonia. This peculiar situation does not mean that expatriates have easy access to Estonian social benefits. Those countries that host large Estonian expatriate populations have started to establish an active exchange of demographic and welfare information with Estonia. For instance, Estonia and Finland are now working on making the exchange of data on health and unemployment automatic. The two countries have already initiated the virtual exchange of medical prescriptions and the aim for 2020 is to start exchanging the medical histories of patients when necessary. Therefore, it would quickly become apparent if an individual was about to receive benefits from both countries. In addition, still being registered in the national residency database does not necessarily simplify the return.

The focus on Estonia's diaspora policies is on how to manage return migrants. As previously mentioned, activity in this area has been scant. According to an 'overview of the repatriation policies and practices' (Beusse 2009), Estonia had supported between 2000 and 2009 the return of 879 people with their repatriation support payment (the previously mentioned one-time payment for returnees). The Foundation for Integration (Intergratsiooni Sihtasutus) is the institution responsible for supporting repatriates. The right of every ethnic Estonian and Estonian citizen to settle in Estonia is provided by Section 36 of the Constitution. In addition, there are two internal documents of the Foundation for Integration on the principle governing the support initiative and how to apply for it. ${ }^{21}$ Applicants need to meet certain

\footnotetext{
${ }^{17}$ ResisiTargalt. Albaania. http://reisitargalt.vm.ee/riigid/albaania/. Accessed 16 April 2019.

${ }^{18}$ See Eures Eesti. Avaleht. http://www.eures.ee/soome/. Accessed 16 April 2019.

${ }^{19}$ Eesti Haigekassa. European Health Insurance Card. https://www.haigekassa.ee/en/kontaktpunkt/healthcare-eu-and-elsewhere/european-health-insurance-card. Accessed 16 April 2019.

${ }^{20} \mathrm{http} / / /$ www.elamarootsi.edicypages.com/eesti-organisatsioone-rootsis. Accessed 16 April 2019.

${ }^{21}$ Integratsiooni Sihtasutus. Migratsioon. https://www.integratsioon.ee/migratsioon. Accessed 16 April 2019.
} 
criteria. They must be an Estonian citizen or an ethnic Estonian who hold an Estonian residence permit and have emigrated from Estonia at least 10 years earlier or were born in a foreign country and have returned to Estonia permanently within the last 6 months. They need to have registered their place of residence in the Population Registry. They must have preserved a connection with the Estonian culture, have respect for the Estonian state and its constitutional order. Their economic and social situation are sufficiently dire to apply for financial support in order to return to Estonia. ${ }^{22}$ Family members of a repatriate receive non-financial help in the form of information and help to navigate bureaucratic issues. Also accompanying children can receive their education initially based on an individual study plan in order to prepare them for Estonian public school (see Beusse 2009). In the context of residence permits, there are not any special regulations for native-born Estonians. There are, however, rules concerning non-Estonian family members of repatriates. Information about the support available for repatriates is mostly disseminated by Estonian embassies and consulates. In terms of possessions, Estonians who have lived in a third country and want to bring back a larger amount than normal of personal items must prove they have lived in that country. Vehicles bought in a third country have to be declared at a customs authority.

Ethnic Estonians returning with a third country citizenship have to apply for a residence permit. Temporary residence permits can be granted if the returnees can prove they have Estonians ancestors. Ethnic Estonians can also apply for reinstatement of the citizenship if they have lost their citizenship as minors, otherwise they will have to apply on the same grounds as foreigners. ${ }^{23}$

In the context of reintegration, Estonia's Foundation for Integration has been organising free Estonian courses at the A2, B1 and B2 socio-economic levels as part of the 'Activities supporting integration in Estonian society' project of the European Social Fund. ${ }^{24}$

People who need to apply for Estonian citizenship must pass an exam in the Estonian language, which also covers Estonia's Constitution and the Citizenship Act. The exam is organized by the National Examination and Qualification Centre. ${ }^{25}$ To support their preparation for the exam, the Foundation for Integration offers free courses on both the Constitution and the Citizenship Act. ${ }^{26}$

\footnotetext{
${ }^{22}$ Integratsiooni Sihtasutus. Tagasipöördumisteotus. https://www.integratsioon.ee/tagasipoordumistoetus. Accessed 16 April 2019.

${ }^{23}$ Politsei ja piirivalveamet. Kodakondsuse taastamine. https://www2.politsei.ee/et/teenused/eestikodakondsus/koda kondsuse-taastamine/. Accessed 16 April 2019.

${ }^{24}$ Integratsiooni Sihtasutus. Eesti keele öpe. https://www.integratsioon.ee/eesti-keeleope-2015-2020-eng. Accessed 16 April 2019.

${ }^{25}$ Politsei ja piirivalveamet. Kodakondsuse eksamid. https://www2.politsei.ee/et/teenused/eestikodakondsus/eksamid-kodakondsuse-taotlemiseks.dot. Accessed 16 April 2019.

${ }^{26}$ Integratsiooni Sihtasutus. Kodakondsuse taotlemise kursused. https://www.integratsioon.ee/ kodakondsuse-taotlemine-kursused. Accessed 16 April 2019.
} 
Concerning other services provided to the returnees, the state does not offer or provide accommodation, which has to be arranged independently, although Intergratsiooni Sihtasutus may partially reimburse travel costs. ${ }^{27}$

Estonian consulates will assist citizens abroad who find themselves in situation of hardship, have a health emergency, etc., in contacting their relatives, protecting their rights or organizing hospital treatments. Consulates can also offer financial help, but usually on the basis of collateral. If collateral does not exists, the consulates can, under special circumstances and with agreement with the Ministry of Foreign Affairs, offer financial help, on the condition the value of the help is returned in full within 90 days. Release from repayment is possible by request to the Minister of Foreign Affairs if the beneficiary of the financial help is certified as bankrupt or an agency of the Estonian state or local government requests release. ${ }^{28}$

Regarding the transportation of earthly remains of expatriates to Estonia, the country of residency is required to inform the Estonian embassy or consulate. If there is no diplomatic representation in the particular country, the relatives of the deceased are instructed to turn for aid to the embassies of other EU countries. Estonia's Consular Law states the consul must assist relatives in transporting the earthly remains to Estonia. However, the embassy must not provide any funds to help with this transportation. ${ }^{29}$

Estonia offers mostly cultural and language oriented programs for its citizens abroad, but services connected to social protection are limited. However, as mentioned earlier, there is a network of Estonian organizations across the world that might receive occasional, mostly project-based funding from the Estonian state, such as the Estonian Guild in London or the Swedish-Estonian Association in Stockholm. These organizations might occasionally provide help for Estonians abroad in legal matters (however this support is oftentimes based on voluntary work by other Estonians abroad). Looking at five core social protection policy areas, we nonetheless found a number of limited interventions by Estonian authorities, which benefit expatriates and citizens abroad.

\subsubsection{Unemployment}

The services provided for expatriates and citizens abroad are defined by Consular Law paragraph $4,{ }^{30}$ and include services such as providing translation and evidence; legalizing a public document issued in a foreign state, at the written request of the person; forwarding the document to the Estonian authorities. In the case of job loss

\footnotetext{
${ }^{27}$ Integratsiooni Sihtasutus. Tagasipöördumistoetus. https://www.integratsioon.ee/tagasipoordumistoetus. Accessed 16 April 2019.

${ }^{28}$ Riigi Teataja. Konsulaarseadus. https://www.riigiteataja.ee/akt/KonS. Accessed 16 April 2019.

${ }^{29}$ Maksu-ja Tolliamet. Surmajuhtum välisriigis. https://www.emta.ee/et/eraklient/reisimine-saadetised-umberasumine/surmajuhtum-valisriigis. Accessed 16 April 2019.

${ }^{30}$ Riigi Teataja. Konsulaarseadus. https://www.riigiteataja.ee/akt/KonS. Accessed 16 April 2019.
} 
and/or seeking unemployment benefits, Estonian consulates can provide documents proving the individual's work record in Estonia (which for Estonians living in the EU can be used to demonstrate eligibility for local unemployment benefits). Nevertheless, in general consulates do not provide any distinct services or financial support to unemployed expatriates.

\subsubsection{Health Care}

Estonia has a public health insurance provided through social tax. Health insurance is available to all who have worked or are working in Estonia, unemployed, and age-related non-working cohorts like pensioners and children. This means that access to healthcare is mostly provided to those who pay taxes in Estonia and is only linked to being registered in the population database for groups such as pensioners, children and unemployed. However, anyone unemployed seeking to access public healthcare must meet certain conditions. For individuals who migrate, a policy providing special access to public health during short visits does not exist. Apart from the EU's free-movers whose access to health is regulated at EU level, there are not any specific services available for individuals abroad. ${ }^{31}$ The general conditions for accessing the Estonian health insurance are stated in the Act of Health Insurance. ${ }^{32}$

However, there are certain exceptions under which expatriates are entitled to access healthcare in Estonia. For instance, Estonia grants free access to healthcare to anyone under the age of 19 who is officially registered in Estonia. In the case of expatriate parents who have maintained their children's residence in Estonia, those children are covered by free health insurance. Estonia also offers free healthcare to people receiving pensions in Estonia (including pensioners living abroad), thus allowing access to retirees who have on retirement become expatriates. Finally, Estonians studying abroad at the university are also covered by health insurance. However, in this case, special applications in order to receive entitlement should be made. These signed applications must contain the name and address of the educational institution, student's full name and personal ID number, the duration of the education abroad, as well as personal status data of the representing person from the educational institution. ${ }^{33}$ In this case, the health insurance must be renewed each year.

\footnotetext{
${ }^{31}$ Eesti.ee. Arstiabi ja ravi välismaal. https://www.eesti.ee/et/tervis-ja-tervisekaitse/tervishoid-jaarstiabi/arstiabi-ja-ravi-vaelismaal/. Accessed 16 April 2019.

${ }^{32}$ Riigi Teataja. Ravikindlustuseseadus. https://www.riigiteataja.ee/akt/104052016008?leiaKehtiv. Accessed 16 April 2019.

${ }^{33}$ Eesti Haigekassa óppimine välisriigis. https://www.haigekassa.ee/kontaktpunkt/ravikindlustuseuroopa-liidus/oppi mine-valisriigis. Accessed 16 April 2019.
} 


\subsubsection{Pensions}

All Estonian citizens living in the EU benefit from the EU coordination concerning pensions. However, there are also bilateral agreements with the Russian Federation, Ukraine and Canada. To receive their state pensions abroad, Estonian citizens must file a corresponding application to the Estonian Social Insurance Board. All pensions are taxed. Different rules apply for individuals living in Estonia and expatriates. Residents in Estonia who receive pensions can get supplementary exemption from income tax, although this does not apply to expatriates. ${ }^{34}$ However, there are some exceptions and people living in certain countries (mostly EU Member States) do not have to pay tax on their pensions as long as they provide the annual certificate concerning tax residency issued by the tax authority of the country of residence. A valid certificate enables the full payment of an Estonian pension, which is to then taxed in the country of residence. If the residency certificate is missing or expired, the pension attracts $20 \%$ income tax.

Since 2018, Estonia requires a proof of life certificate for all individuals who receive an Estonian pension while living in a foreign country. The certificate must be sent to the Social Insurance Board (Sotsiaalkindlustusamet) by the first of March every year. When the certificate is not received by the required deadline, pension payments are stopped. However, certain exceptions exist in terms of having to provide proof of life. The certificate is not a requirement for either people with Estonian citizenship or recipients of an Estonian pension who live in Russia, Latvia, Lithuania, Moldova and Ukraine. As an alternative to sending a life certificate, citizens can also visit a local office of Sotsiaalkindlustusamet to receive their pension. Expatriates have the option of applying for life certificates either from social institutions in the country of residence or from the Estonian consulate. The consulate issues documents as per paragraph $\S 30$ of Consular Law (Proof of action, Tõestamistoiming).

Estonia also has social security agreements with Canada, Ukraine and Russia. The agreements concluded with Canada and Ukraine provide payment of pensions under the same conditions as in EU Member States. The agreement with the Russian Federation provides for Estonia paying pensions to Russians living in Estonia and the Russian Federation paying pensions to Estonians living in its territory. The payment of pensions between Estonia and Russia is regulated by the Estonian-Russian pension insurance agreement (Eesti-Vene pensionikindlustuse koostöölepe). One issue this agreement regulates is the payment of pensions earned during the Soviet period. This is important because for pensioners residing in many other countries, any work done in the period before Estonia regained its independence is often not counted for their required period of pension contributions. The mandatory period is 15 years. This particular agreement makes an exception for Estonians residing in Russia. Additionally, the agreement states that if a person does not have the

\footnotetext{
${ }^{34}$ For pension-related regulations, see: Republic of Estonia Social Insurance Board. Receiving pensions from abroad and receiving pensions abroad. http://www.sotsiaalkindlustusamet.ee/en/ receiving-pension-abroad-and-receiving-pension-abroad. Accessed 16 April 2019.
} 
necessary contribution period in one country (15 years in Estonia, 20 years in Russia), the work periods in the two countries will be aggregated. Moreover, the cooperation agreement regulates the starting point of pension payments, as the age for receiving pensions is considerably lower in Russia. The treaty was issued on 14th of July 2011, but is now under revision. ${ }^{35}$

The pension agreement between Estonia and Canada stipulated that an individual's work period in Canada is counted as equal to the period of working in Estonia if the person is not entitled to compensation because he/she does not have sufficient periods of time to be taken into account under the legislation of one of the Contracting Parties. The conditions for pension payments in this case are regulated by the Act of Social Insurance between Estonia and Canada, approved in 2005. ${ }^{36}$

The pension agreement with Ukraine is regulated by the Estonian and Ukraine Social Insurance Act approved in 2010. As mentioned earlier, the pension payment between the two states is largely regulated in the same manner as the EU pension coordination. ${ }^{37}$

\subsubsection{Family-Related Benefits}

Assistance in issues of family is regulated by the Law for family related matters $\S$ 3. ${ }^{38}$ The legislation stipulates that, if needed, the birth of an Estonian citizen can be registered by consular authorities. However, the birth cannot be registered if it has already been registered in a foreign country. If parents want to register a child whose birth certificate was authorized anywhere but at the Estonian registry, they need to provide legalized documents translated into Estonian, English or Russian.

Birth-related support grants are available if at least one parent is registered in the population register in Estonia and the family does not receive any similar benefits from other countries according to the Family Benefits Acts (Perehüvitiste seadus ${ }^{39}$ ). Other family benefits are usually regulated by residency criteria and thus are not available to expatriates.

\footnotetext{
${ }^{35}$ Eesti Vabariigi ja Venemaa Föderatsiooni. https://www.sotsiaalkindlustusamet.ee/sites/default/ files/content-editors/Dokumendid/evjavfpensionikindlustuslepingeesti.pdf. Accessed 16 April 2019.

${ }^{36}$ Riigi Teataja. Eesti Vabariigi ja Kanada vaheline sotsiaalkindlustusleping. https://www.riigiteataja.ee/akt/958572. Accessed 16 April 2019.

${ }^{37}$ Riigi Teataja. Eesti Vabariigi ja Ukraina sotsiaalkindlustusleping. https://www.riigiteataja.ee/ akt/207112011002. Accessed 16 April 2019.

${ }^{38}$ Riigi Teataja. Perekonnaseisutoimingute seadus. https://www.riigiteataja.ee/akt/PKTS. Accessed 16 April 2019.

${ }^{39}$ Riigi Teataja. Perehuvitiseseadus. https://www.riigiteataja.ee/akt/128122017062. Accessed 16 April 2019.
} 


\subsubsection{Economic Hardship}

The provision of subsistence allowance in Estonia is administered by local municipalities. In order to apply, an individual needs to provide documentation for all monthly costs. The subsistence allowance is not available to expatriates. However, Estonians who find themselves in an emergency when abroad can apply to the local consulate for financial assistance. Repayment is usually due after 90 days after receiving it.

\subsection{Conclusions}

As shown in this chapter, Estonia's diaspora policy is more oriented towards language and culture maintenance abroad. According to the evaluation report of the Program for Compatriots (Rahvuskaaslaste Programm), a survey conducted in 2015 found that $72 \%$ of Estonians living abroad do not feel that the Estonian state needs them and $43 \%$ do not feel that there is a positive attitude towards Estonians in Estonia. For instance, Lithuania's 'compatriots' conference ${ }^{40}$ presents awards to distinguished Lithuanians living abroad, whereas in Estonia, the same kind of event merely provides a practical overview of the progress of the program (see Jakobson 2017). The results of the evaluation report indicate that whereas there have been investments in maintaining Estonian culture and language abroad, there are other fields concerning identity politics that have been overlooked. In addition, so few returnees took up the offer of financial support that this part of the program has not had a particularly large impact.

Previous research show that the Estonian policy towards its diaspora and returnees has been influenced by neoliberal ideology. The Estonian diaspora is often viewed, especially when including the more recent migrants, as a group of selfsufficient individuals, rather than a culturally united community. Furthermore, when discussing the potential to return, policy discourses often emphasize free choice and downplay the state's role (see Saar and Jakobson 2015). Fröhlig, Saar and Runfors (2017) also point out that Estonian policy experts believed that the main way to attract returnees is by reviving the country's economy that could lead to increasing the salaries. Other aspects, such as increased social benefits, were rarely discussed by the experts. The idea of expatriates as being self-sufficient is also visible from the initiatives such as Global Estonians, which focus on developing business relations between expatriates and the residents in Estonia.

Such attitudes are exemplified by the support structure or rather lack of it in all five policy areas of social protection analysed in this chapter. However, some support is often provided by local diaspora organizations, but they are rarely financed

\footnotetext{
${ }^{40}$ The Compatriots' Conference was a onetime event in 2015 to describe the impact of the second round of the Program for Compatriots.
} 
by the state on a regular basis and are dependent on project funding. This means that local diaspora organizations most often have versatile funding resources, with the Estonian state being only one of their supporters.

Based on expert interviews conducted by Fröhlig, Saar and Runfors (2017) as well as current political discussions, it is unlikely that Estonia will invest more in any of the key support areas or allow easier access to these benefits for expatriates. Whereas the country has shown some developments inspired by social-democratic approaches, its policies are characterized by a strong neoliberal undertone. Hence, there are definite developments that can be observed in diaspora politics, especially that policies have started to move from a cultural basis to a business orientation. However, these developments are unlikely to include significant social benefitrelated support for the diaspora or returnees [some inklings towards this can be observed in the final report of the Program for Compatriots (Aksen et al. 2015)]. Rather it is more likely that there will be an increased effort to engage expatriates for business purposes, as the initiative 'Global Estonian Network' has shown.

Among the areas of possible evolution, we can find the readiness for accommodating children and, to some extent, family members of Estonian returnees. The need for these kind of developments is also mentioned by the evaluation report for Rahvuskaaslaste Programm compiled in 2015 (Aksen et al. 2015). The report suggests assigning a support person for the returnees who is meant to assist them in various issues. In recent years, Estonia has also accepted some refugees and has been faced with the need to introduce more language preparation classes and to think about integrating migrant children into Estonian schools. Even though Estonia has had years of experience with the Russian-speaking minority, the issues there have been dealt with by introducing a parallel school system. Less developments can however be seen in terms of accommodating family members that might not have Estonian roots.

Acknowledgements This chapter is part of the project "Migration and Transnational Social Protection in (Post)Crisis Europe (MiTSoPro)" that has received funding from the European Research Council (ERC) under the European Union's Horizon 2020 research and innovation programme (Grant agreement No. 680014). In addition to this chapter, readers can find a series of indicators comparing national social protection and diaspora policies across 40 countries on the following website: http://labos.ulg.ac.be/socialprotection/.

\section{References}

Adamson, A. (2009). Rahvuskaaslaste Programm. Sirp. http://sirp.ee/s1-artiklid/varia/rahvuskaas laste-programm-20092013/. Accessed 16 Apr 2019.

Aksen, M., Aruoja, K., Lees, K., Käger, M., Sammul, M., Vahaste-Pruul, S., Tatar, M., Themas, A., \& Varblane, U. (2015). Rahvuskaaslaste Programmi Mõjuuuring 2015. Tartu: RAKE and Institute for Baltic Studies University of Tartu.

Anniste, K., Tammaru, T., Pungas, E., \& Paas, T. (2012). Emigration after EU enlargement: was there a brain drain effect in the case of Estonia? University of Tartu FEBA Working Papers. https://papers.ssrn.com/sol3/papers.cfm?abstract_id=2070036. Accessed 16 Apr 2019. 
Beusse, M. (2009). Repatriation policies and practices. Estonian Migration Fund, a comparative overview of the repatriation policies and practices of other EU Member States. https://ec.europa. eu/migrant-integration/index.cfm?action=media.download\&uuid=299ECC14-A0B0774C-D3A44B5898CECD11. Accessed 16 Apr 2019.

Fröhlig, F., Saar, M., \& Runfors, A. (2017). Swedish and Estonian discourses on free EU movement, welfare and belonging. Welfare State Futures Working Paper 3/2016. https://welfarestatefutures.files.wordpress.com/2018/02/wsf-working-paper-transwel-3-2016-web.pdf. Accessed 16 of Apr 2019.

Jakobson, M.-L. (2017). Hargmaisuspoliitika. In T. Tammaru (Ed.), Eesti Inimarengu Aruanne 2016/2017 (pp. 111-118). Tallinn: SA Eesti Koostöö Kogu.

Madison, J. (2018). How to keep the Estonian flame alive abroad. Diplomaatia. https://icds.ee/ how-to-keep-the-estonian-flame-alive-abroad/. Accessed 16 Apr 2019.

Raus, L. (2010). Pevkur: Tuhandete soov Eestist lahkuda pole problem. Postimees. https://www. err.ee/414300/pevkur-valjaranne-ei-ole-probleem. Accessed 16 Apr 2019.

Reimaa, A.-L. (2017). Mida tasub teada rahvuskaaslaste programmist. Eesti Kultuuriseltside ühendus.

Saar, M. (2016). Individualisation of migration from the East? Comparison of different sociodemographic groups and their migration intentions. Studies of Transition States and Societies, $8(3), 45-59$.

Saar, M. (2018). Using reflexivity to explain variations in migration among the highly-skilled. Identities, 26(6), 688-705.

Saar, M., \& Jakobson, M.-L. (2015). Väljarände põhjendused ja rändajate muutuv kuuluvus. In R. Vetik (Ed.), Eesti Inimarengu Aruanne 2014/2015 (pp. 118-123). Tallinn: SA Eesti Koostöö Kogu.

Sippola, M. (2013). The awkward choices facing the Baltic worker: Exit or loyalty. Journal of Baltic Studies, 44(4), 451-473.

Tammaru, T., Kumer-Haukanõmm, K., \& Anniste, K. (2010). The formation and development of the Estonian diaspora. Journal of Ethnic and Migration Studies, 36(7), 1157-1174.

Open Access This chapter is licensed under the terms of the Creative Commons Attribution 4.0 International License (http://creativecommons.org/licenses/by/4.0/), which permits use, sharing, adaptation, distribution and reproduction in any medium or format, as long as you give appropriate credit to the original author(s) and the source, provide a link to the Creative Commons license and indicate if changes were made.

The images or other third party material in this chapter are included in the chapter's Creative Commons license, unless indicated otherwise in a credit line to the material. If material is not included in the chapter's Creative Commons license and your intended use is not permitted by statutory regulation or exceeds the permitted use, you will need to obtain permission directly from the copyright holder.

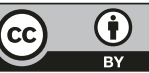

